\begin{tabular}{|l|l|l||}
\hline \multicolumn{2}{|c|}{ PublisherInfo } \\
\hline \hline PublisherName & $:$ & BioMed Central \\
\hline \hline PublisherLocation & $:$ & London \\
\hline \hline PublisherImprintName & $:$ & BioMed Central \\
\hline \hline
\end{tabular}

\title{
Transplastomic tomatoes
}

\begin{tabular}{|l|l|l||}
\hline \multicolumn{2}{|c|}{ ArticleInfo } \\
\hline \hline ArticleID & $:$ & 4192 \\
\hline \hline ArticleDOI & $:$ & $10.1186 /$ gb-spotlight-20010903-01 \\
\hline \hline ArticleCitationID & $:$ & spotlight-20010903-01 \\
\hline \hline ArticleSequenceNumber & $:$ & 263 \\
\hline \hline ArticleCategory & $:$ & Research news \\
\hline \hline ArticleFirstPage & $:$ & 1 \\
\hline \hline ArticleLastPage & $:$ & 2 \\
\hline \hline & & RegistrationDate : 2001-09-03 \\
ArticleHistory & $:$ & OnlineDate \\
\hline \hline ArticleCopyright & $:$ & BioMed Central Ltd2001 \\
\hline \hline ArticleGrants & $:$ & \\
\hline \hline ArticleContext & $:$ & 130592211 \\
\hline \hline
\end{tabular}




\section{Jonathan B Weitzman}

Email: jonathanweitzman@hotmail.com

Plants have three genomes, each contained in a separate cellular compartment; the nucleus, the mitochondrion and the plastid. The higher plant plastid genome is a double-stranded circle of 120-160 $\mathrm{kb}$, encoding about 130 genes. The development of plastid transgene applications has been hampered by the technical limitations of tissue culture and regeneration protocols. In the September issue of Nature Biotechnology, Ruf et al. report the development of a plastid transformation system for tomato, Lycopersicon esculentum, and generation of the first edible transplastomic fruits (Nature Biotechnology 2001, 19:870-875). Ruf et al. developed new transformation vectors for efficient delivery of foreign genes to chlororoplasts. They then created tomato plants expressing a selectable spectinomycinresistance marker gene, aadA. Transformation procedures were modified by using low-light conditions and an extended selection phase, to optimize success. Ruf et al. found that the AadA protein was expressed at high levels in the tomato fruit, comprising about $0.5-1 \%$ of the total soluble cellular protein. This technology will open up new possibilities for the development of plants expressing edible vaccines, antibodies ('plantibodies') and drugs.

\section{References}

1. The chloroplast genome

2. Engineering chloroplasts: an alternative site for foreign genes, proteins, reactions and products.

3. Nature Biotechnology, [http://biotech.nature.com]

4. Transgenic plants as factories for biopharmaceuticals.

This PDF file was created after publication. 